\title{
Social Wellbeing as a Criterion of Structural Policy Efficiency
}

\author{
M. Gasanov ${ }^{\mathrm{a}}$, S. Zhironkin ${ }^{\mathrm{a}^{*}}$ \\ * Corresponding author: zhironkin@inbox.ru \\ ${ }^{a}$ National Research Tomsk Polytechnic University, Lenin Avenue 30, Tomsk 634050, Russia, E-Mail: hursyd1@yandex.ru
}

\begin{abstract}
http://dx.doi.org/10.15405/epsbs.2016.02.16

Social wellbeing of nation is not only a constitutional goal of the state, but, above all, the quintessence of all largescale economic and political transformations. In Russian economy the gap between the objectives of social and structural policy is broadening. As a result, in the course of reforms the "vicious circle" of structural problems and reducing the wellbeing of Russians arose and deepens now. This circle consists of the following problems: deindustrialization of Russian economy - decreasing of social wellbeing - decreasing of the necessary for neoindustrialization of economy stable social group - the weakening of factors targeted to the structural changes - the continuation of de-industrialization. Structural economic changes along with the improvement of macroeconomic dynamics should be aimed at socially important priorities of economic development, without exception. In that context, we suppose the ultimate criterion of structural changes to be the growth of social wellbeing of Russians by increasing labor productivity, the establishment of new high-tech industries, and the formation of new sustainable social groups in the neo-industrialization of Russian economy.
\end{abstract}

(C) 2016 Published by Future Academy www.FutureAcademy.org.uk

Keywords: Social wellbeing; de-socialization; structure of economy; deindustrialization; neo-industrialization; social groups.

\section{Introduction}

The set of structural problems unsolved during the reform period of Russian economy, formed on the pre-reform stage, led to its de-industrialization. Structural problems of economy and its deindustrialization threaten significantly the social wellbeing of Russians. So they must be studied and analyzed in complex with the formation of special target social group. This social group should be the leader of social wellbeing growth, aimed to be forms within governmental structural policy and to become a criterion of its efficiency. 


\section{Problem Statement}

Some authors defined de-industrialization as negative structural changes in the economy under the influence of technological production level decreasing (Gasanov, Zhironkin, 2015), another - as a reduction of industrial scientific potential (Koshanov, 2010). De-industrialization of Russian economy can be measured with reducing of the manufacturing share in GDP (in 1996-2013 from 48\% to 35\%), and in the industry itself - as reducing of the manufacturing sector (in $2006-42 \%$, in $2010-38 \%$, according to the method of value added (Rosstat Data, 2013)). De-industrialization of Russian economy in the period of market reforms is caused by technological degradation of industry deprived it not only international but also domestic competitiveness. In particular, during the twenty years of market reforms in Russia the share of high-tech industries (electronics, biochemistry, pharmaceuticals, aviation, etc.) has decreased from $20 \%$ to $10 \%$ of GDP (in the USA it increased from 50 to $60 \%$ ), key manufacturing industries (engineering, organic chemistry, professional equipment, etc.) has decreased from 60 to $50 \%$. The share of new industries - nanotechnology, satellite building, microelectronics, production of biomaterials, bioenergy - did not exceed $0.5 \%$ of GDP (in the United States it reached $6 \%$ ). While the share of miming sector (the basis of the economy in the leading countries in the second half of the 19th century) grew from 20 to $30 \%$ of GDP in Russia, in the US it reduced to a few percent by the 21 th century (Rosstat, 2012).

\section{Research questions}

The strongest negative structural changes have occurred in the field of innovation and technology, pushing Russia back to the position of 1950s (Zhironkin, 2001). The refusal of the state to finance science and the lack of interest to it from business led to the decreasing of organizations involved in R\&D (Research and Development) from 4.5 to 3,3 thousand employees from 1992 till 2012, i.e. more than a third, and project organizations, creating items ready for implementation in production decreased in 13 times (from 495 to 37). During 2010-2013 Russia's contribution to the world science provided only $2.2 \%$ of the new research. Only $6 \%$ of scientific organizations in Russia were involved in innovation activities (in the US - 75\%). As for business less than $1 \%$ of Russian large companies are engaged in R\&D, in the US - 65\%. As a result, the competitiveness of Russian economy on the world market has reduced in four times since 1998, so the manufacturing of products of the 6th technological mode (Glaziev, 2012) in Russia in 2012 amounted to about 1.5 billion dollars, and in South Korea 350 billion dollars (Rosstat, 2012).

Our research allowed us to determine the main cause of de-industrialization in Russia economy as a lack of state structural policy aimed at adapting industry to new market conditions, maintaining interfirm business links, ensuring the flow of long-term loans and investments, supporting the scientific potential.

Other causes of de-industrialization of Russian economy in transition are described by a number of economists: the lack of adequate market institutions (Kornaj, 2000), the financial crisis and the growth of financial gambling (Shmelev, 1998), high costs and lack of competitiveness in most industries (Kurnysheva, Lykov, Idrisov, 2008), one-time break of economic ties in the specific conditions of distribution of productive forces in the USSR (Grandberg, 2002). 
Some economists understand de-industrialization as a process of relative reduction of material production that occurs in technologically leading countries. For example, the share of processing industries in GDP of the UK has decreased from $22 \%$ to $13 \%$ in 1990-2009 and in the USA - from $21 \%$ to $15 \%$ (Tolkatchev, 2010). However, in these countries material production is replaced by high-tech services (internet programming, cloud computing, modern financial services and so on), while the old capital-intensive industries are gradually transferred by American, British, Japanese corporations to China, Taiwan, Brazil, Mexico, India and Eastern Europe.

On the contrary, in Russian economy de-industrialization looks like a process of degradation of industry with a general increase of its share in GDP in the period of market reforms - from 68 to $46 \%$ (Rosstat, 2012). That's why we named the impact of de-industrialization on Russian society a "structural de-socialization". It stands for continuous destruction of social groups which can provide innovative development and neo-industrialization of Russian economy, build the ground of a positive structural shift.

This destructive process in social wellbeing is getting stronger due to the failure of state countermeasures. Social groups necessary for the technological development of Russian industry must be the elite target groups - scientists, innovation managers, employees of high-tech enterprises. New social relations (among government, business and science), new social roles (innovative entrepreneurs, scientists, "freelancers", private venture investors - "business angels"), incentives of highly intellectual labor should be formed among them. However, from the beginning of the 1990s elite social groups which can provide a positive structural changes of Russian economy, have not received sustainable support; on the contrary, the destruction of the USSR "intellectual legacy" is continuing.

\section{Research methods}

Structural de-socialization of Russian economy can be seen in breaking of important social relations:

- collapse of priority neo-industrialization social groups - target elite groups. The most target and prestigious social group in the Soviet Union until the mid-1980s was engineers and industrial managers which represented the basis of the industrial type economy. Target groups of postindustrial society being formed in the advanced countries contain innovative, creative-engineering, researching individuals. Technological simplification of Russian economy and the degradation of production brought to the place of the elite group those which get mineral and administrative rent (managers of mining companies and government officials) and profits from redistribution (entrepreneurs of speculative promotion, commercial staff). In Russia these groups do not have any stable relations either with the "productive" group of engineers and production managers, or creative and researching groups as they do not contribute to any recovery of manufacturing industries or new technologies importing;

- degradation of social situations in conditions of the privatization during economic downturn and financial crisis of the 1990s., unresolved intellectual property rights, administrative pressure on business by the state and elimination of market participants, the nationalization of the banking and financial assets at the end of 2000s., the expansion of oligopolies. This was a result of negative changes in Russian economy structure where the mineral rent went to the place of the main source of corporate, 
government and personal income, and business initiative was constrained by pro-fiscal economic policy, and intellectual capital found no implementation at all. And that degradation of social situations by which we explain increasing gap between lower and higher layers of Russian society;

- deprivation of motivation to creative labor. If on the pre-industrial stage the most valuable creative labor for the society was agricultural, and on the industrial stage - the work at factories and plants, then as the world is getting closer to the post-industrial stage, the value of scientific creativity, producing of intangible assets is increasing. In Russian economy the growing problems of the industrial, innovative-technological structure of economy led to weakening of incentives for productive and honest work in industry and decreasing of social status of innovation activity. But this motivation is not supported either by the state or entrepreneurs. On the contrary, employers appreciate absolute loyalty and unquestioning obedience of employees much higher than creativity, productivity, which deprive their work incentives and decrease the value of labor. All of this reflects the continuing low labor productivity. In general, the labor productivity in Russian economy is lower than in the USA and Western Europe in industry in 2.6 times, in agriculture in 3.1 times (Fomchenkov, 2014). At the same time, according to the expert's estimation, $54 \%$ of the households gross income is not generated by industry but trade and commerce, administrative, financial, rental activities; while the share of "shadow" and unreported income is as high as 20\% (Golovachev, 2013);

- negative changes of social roles and results of their performance. In the process of deindustrialization along with reducing of innovation and technological level of industry and aging of fixed assets, we can observe inevitable decreasing of personal opportunities and social wellbeing. Russian society is gradually "getting rid" of effective entrepreneurs, innovators, scientists and inventors, and their number is inevitably declining (for the period of 1992-2012 in four times) (Glaziev, 2013). As a result, the "vicious circle" of structural de-socialization is being strengthened. This circle consists of the following: the deterioration of segment and competitive structure (decreasing of market sector, strengthening of administration and monopolization of economy) - diminishing the role of intellectual and business elite groups - enhancing the role of bureaucratic and raw materials elite groups - further weakening of market sector and competition. Not opposing it, the state deprives the economy of social ground of neo-industrialization, "cements" the high costs productions, based on the extraction of non-renewable minerals;

- decreasing of social mobility, slowing the most important social lifts, especially higher education, scientific research and obtaining scientific degrees. This can't but make the structure of personal income distribution worse. Thus, the value of decile rate (the total income ratio of $10 \%$ of the richest and the poorest) in Russia in 2010-2013 was 17-18 (in Sweden - 4, in Germany - 6, in the USA - 9) (Odincova, 2013). High-level of vertical social mobility, including generational, the factors of which are professional career, small and medium entrepreneurship, innovation activity, public services development, can be observed in the USA and Western Europe today. Due to the development of information technology, high-tech production of goods and services, mentioned above social lifts are accelerating, and a new generation becomes more successful, not inheriting the funds but using knowledge in innovative business. For example, in the United States 11 famous representatives of high-tech industry are in the first thirty of billionaires (Forbes, 2014). In Russia, on the contrary, there 
http://dx.doi.org/10.15405/epsbs.2016.02.16

eISSN: 2357-1330 / Corresponding Author: Zhironkin S., Email:zhironkin@inbox.ru

Selection and peer-review under responsibility of the Organizing Committee of the conference

is a tendency to inherit administrative posts and the formation of "bureaucratic rent", which is typical for the "third world countries".

Despite the preservation and deepening of social problems, Russian society and the state have only come to an understanding of the social wellbeing as the ultimate goal of market reforms. GDP growth, globalization of national large-scale business, increasing of political influence in the world, the expansion in the global resource market - are the national priorities of economic development. For Russia wellbeing is still an antipode of poverty - a problem which has not been solved yet (by 2013 $13 \%$ of the population were below the poverty line (Dobrynina, 2013), and by 2016 there is a risk of becoming poor for $25 \%$ of the population).

The existence of social wellbeing problems increased the risk of forming Russian society structure similar to the caste one (like in India long time ago), when the citizens, far from the major officials and oligarchs, may use social lifts of modern society (education, science, entrepreneurship) only nominally. This is fully contributed by the existing institutional structure of Russian economy, in which most of formal and informal institutions are established by the state and oligarchic natural resource business, fixing their relationship in legal acts and deeds, regulations, and contracts. On the contrary, stimulation of innovative entrepreneurship by the state and manufacturing production are de-institutionalized, and increasing social mobility remains declarative.

\section{Findings}

We associate overcoming of de-industrialization of Russian economy with its neo-industrialization that is carrying out the policy of well-ordered structural reforms in the following three ways.

Firstly, the establishment of institutional, financial, social, technological and market conditions of innovative development in key sectors of Russian economy (coal, petroleum, chemical, foundry, mechanical engineering), as well as the recovery of electronics, aircraft and shipbuilding on the modern technological ground.

Secondly, the development of the most advanced high-tech industries (recuperation power, laser manufacturing, nano-robotics, the production of new alloys and plastics, biochemistry, etc.) based on the convergent technologies. Key and processing industries should be technologically upgraded to become the resource base and, at the same time, consumers of "breakthrough" innovations of high-tech industries.

Third, the deep changes in the structure of market competition and social groups must create the necessary conditions for neo-industrialization and lead to the growth of social wellbeing.

For all this, the structural policy in Russian economy should be directed at achieving, finally, the significant social goals. Growth prospects of social wellbeing in the process of Russian economy neoindustrialization must be based on the formation of neo-industrial social group in it.

We consider target neo-industrial social group to be an innovative class - the basics producing layer of advanced industrial and post-industrial society. Determining its structure, we took into account the opinion of a number of economists - researchers of the theory of postindustrial economy about the content of neo-industrial social group: employed in the information business (Toffler,1990), highly educated managers and employees of modern corporations, scientists and experts working in industries 
of intangible goods production (Inozemtsev, 2000), any modern workers with rare skills that do not have readily available substitutes (Clement, Miles, 1994).

Taking into consideration Russian peculiarities, we have added the following categories of citizens to neo-industrial social group which must be the leader in the social wellbeing growth:

- university students - future professionals of information technology, biochemical, radioelectronics and other high-tech industries (in 2012 in Russia - 2.3\%, in USA - 4.5\%, in Germany $6.2 \%$ of total employment (World Bank, 2014));

- employees of manufacturing industries (in Russia - 21\%, in the USA - 34\%, in Japan - 56\% (World Bank, 2014));

- employees of scientific organizations, university teaching staff involved in research and employed in innovative firms (in Russia - 0.1\%, in the USA - 1.1\%, in France - 1.8\% (World Bank, 2014)).

- private venture capital investors («business angels»), financing innovative projects for consumer market.

So, to achieve steady growth of social wellbeing in Russia it is necessary to conduct antidesocializing structural governmental policy which should include the following:

- the state contract for mass training of Russian specialists in leading foreign universities in the areas of critical and breakthrough technologies, with the obligatory subsequent employment in companies - residents of innovation clusters and the areas of new technologies commercialization (called "technology parks" in Russia);

- the development of state guarantees of employment for highly skilled workers and university graduates in the innovation clusters and technology parks;

- the exemption of payroll in innovative firms, R\&D departments and organizations from all taxes and the wages of employees, engaged in the innovation sector, from income tax;

- embedding an obligatory requirement of training and retraining for highly qualified personnel into investment projects supported by Russian Venture Company and other state venture funds;

- restoring the prestige of scientific work and employment by scientific and research organizations, encouraging social mobility, based on highly profitable innovation activity, invention and engineering creativity. This requires legal protection of intellectual property rights, mechanisms of compensation during commercializing, development of the market of patented technologies and know-how, the guarantees of getting proper rent for owners of intellectual capital.

\section{Conclusion}

So it should be mentioned that target role of social wellbeing puts it to the position of ultimate criterion of neo-industrial structural reforms. They finally must become the main means of raising the life quality and economic wellbeing of Russians. As the main condition of that we have identified the formation of social ground of neo-industrial structural changes in Russian economy, which is closely related to its technological development. The Russian government must take into account the following self-sustaining chain in the implementation of strategic planning: "encouraging new technologies commercializing - expansion of neo-industrial social group - further impulse to the development of innovation - the growth of social wellbeing." 


\section{Acknowledgements}

The authors would like to thank Galina Barisheva, Victor Kanov for their discussion during the study. We thank the anonymous referees for their constructive and useful comments on the paper.

This work was performed by the authors in collaboration with Tomsk Polytechnic University within the project in Evaluation and enhancement of social, economic and emotional wellbeing of older adults under the Agreement No.14.Z50.31.0029 (19th of March, 2014).

\section{References}

Gasanov M. \& Zhironkin S. (2015) Neo-industrial Base of Network Social Prosperity in the Russian Economy. Procedia - Social and Behavioral Sciences. 166, 97-102.

Koshanov A. (2010) Forced industrialization and innovation strategy. Obshestvo i economica. 9, 4-26.

Gross Domestic Product and Gross Added Value aggregated on economic activity (2013). Rosstat. URL: http://www.gks.ru/free_doc/new_site/vvp/tab10.xls

Zhironkin S.A. (2001) Governmental factoring development of TEK Kuzbass. Ugol', 6, 62.

Glaziev S. (2012) "The Strategy-2020" - Anti- modernisation act. Russian Economic Journal. 2, 3-6.

Russia and the World Countries (2012) Rosstat. URL: http://www.gks.ru/bgd/regl/b12_39/Main.htm

Kornaj Y. (2000) The Socialistic System. Political Economy of Communism. Moscow: Voprosy Ekonomiki Magazine Pub., 458.

Shmelev N. (1998) Crisis Inside the Crisis. Rossijskij jekonomicheskij zhurnal. 10, 9-11.

Kurnysheva I., Lykov S. \& Idrisov A. (2008) Competitiveness and structural modernization problems. Economist. $10,39-47$

Grandberg A. (2002) The strategy and the problems of steady development of Russia in XXI century. Moscow: Ekonomika Pub., 422.

Tolkatchev S. (2010) The search for the Russia neo-industrialization model. Economist. 12, 24-43.

Fomchenkov T. (2014) They can not be reached. Rossijskaja gazeta, The $2^{\text {nd }}$ of Julay. Available at http://www.rg.ru/2014/07/02/proizvoditelnost.html

Golovachev V. (2013) In Russia in 2012 "black wages" were paid of 9 trillions. Information Agency "Newsland". Available at http://newsland.com/news/detail/id/1135304/

Glaziev S. (2013) What happens when officials start ruling the science, can be seen by "Rosnano" and "Skolkovo" failing. Komsomolskaya Pravda, The 12nd of August. Available at: http://www.kp.ru/daily/26118.5/3012320/

Odincova E. (2013) The amount of middle-class estimation using criteria of labor market position and wellproviding. Uroven zhizni naselenija regionov Rossii. 9 (187), 82-85.

Forbes Rating (2014). Available at http://www.forbes.ru/reitingi-photogallery/251513-bogateishie-lyudi-planety2014-reiting-forbes/photo/1

Dobrynina, E. (2013) Sociologists discovered why the poverty in Russia decreased and money-seized people increased. Rossijskaja gazeta. Federal'nyj vypusk, 6109, 12.

Toffler A. (1990) Powershift. Knowledge, Wealth and Violence at the Edge of the 21st Century: N.Y., 268.

Inozemcev V. (2000) Modern post-industrial society: The nature, contradictions, prospects. Moscow, 217.

Clement W. \& Myles J. (1994) Relations of Ruling: Class and Gender in Postindustrial Societies. Montreal, 270.

World Bank Data (2014). Available at http://data.worldbank.org/indicator 